\title{
An Experimental Study Skills To Enhance Reading Skill
}

\author{
Dr.L.Bapitha ${ }^{1}$, Dr. S. Gunasekaran ${ }^{2}$ \\ ${ }^{1}$ Department of English Anna University University College of Engineering Ramanathapuram, Tamilnadu, India \\ ${ }^{2}$ Department of English Anna University University College of Engineering Dindigul, Tamilnadu, India
}

\begin{abstract}
Reading, Knowledge, Motivation Reading is not only one of the most important skills in language teaching, but also one of the main objectives of learning English in general. Many factors such as students' background knowledge, motivation, interest, organization of the texts and study skills may affect reading skill. The purpose of this study was to investigate whether teaching study skills would increase students' reading comprehension ability or not. To achieve this goal an experiment was carried out at Anna University College of Engineering, Ramanathapuram, Tamilnadu, India during the second semester of 2016-2017. The results of the study supported the argument that skills in reading depend on the precise coordination of a number of special reading skills and there is a significant relationship between the knowledge of study skills and reading comprehension.
\end{abstract}

Keywords:

Study Skills, Reading skill, knowledge, Motivation, Precise, Coordination, Special reading skills.

Article Received: 10 August 2020, Revised: 25 October 2020, Accepted: 18 November 2020

\section{I.Introduction}

Most English teachers would agree that reading is an important quality and ability to help learners not only to improve their skill of a language, but also to foster new ways of upgrading it. According to Bright and McGregor (2015) where there is little reading there will be little language learning. Through the history of language teaching three different views are assigned to reading.

First of all, Linguistic models in which reading are considered as nothing more than establishing a relationship between sounds and symbols. Secondly, based on the contribution of psychology to the learning theory and its impact on reading, the psycholinguistics model emerged as a new perspective. In this line of thought Goodman defines reading as "psycholinguistic guessing game". However, in Communicative model Widdowson (2015) sees reading as a co-operative activity between the decoder and the encoder. According to Widdowson, reading is regarded not as a reaction to a text but as an interaction between the writer and the reader mediated through the text.

According to Samuels (2014), constructing a meaning out of the message depends on factors which are inside the mind of a receiver as well as on outer environmental factors which are external to the receiver. The reader related characteristics that effect comprehension most directly are the reader's background knowledge and experiences, motivation and interest, culture, and the ability to read the words easily and understanding organization of the text. Moreover, Clarke and Silberstain (2014) emphasize that skill in reading depends on precise coordination of a number of special skills such as skimming, scanning, thorough comprehension and critical reading. These skills are either language skills (knowledge of vocabulary, syntax, etc.) or reading skills.

Coady (2014) maintains that there are great numbers of students having a high level of proficiency in English still read very slowly and with poor comprehension. In short, study skills along with language skills improve students reading comprehension.

\section{Objective of the study}

The purpose of the present study is to determine the effect of the knowledge of reading skills on reading comprehension. If the knowledge and type of skills are significant to reading comprehension, then this aspect of the reading skill should be emphasized.

\section{Hypothesis}

This research was aimed to find out, if there was any relationship between study skills and reading comprehension ability among the first year BE students at Anna University College of Engineering, Ramanathapuram, Tamilnadu, India. A null hypothesis was selected as follows 
1. There will be a significant gain in scores in achievement in reading comprehension between the pre and post-treatment tests.

2. There will be no significant relationship between study skills and students comprehension ability.

\section{Methodology}

In the present study, the experimental research method was followed and a single group pre-test, post-test design was adopted. Sample

A Sample of 76 pupils studying in first year $\mathrm{BE}$ (Bachelor of Engineering) Course was selected by random sampling techniques from Anna University College of Engineering, Ramanathapuram, Tamilnadu, India. They were male and female students majoring in Civil and Mechanical Engineering, they are proficient in their mother tongue language (Tamil Medium) were the experimental group and the control group were the students of English Medium . Apart from taking the two sessions of pre test and post test, the control group received no special treatment. However, the experimental group was provided not only with the textbooks, but also with practical application of specific reading skills and sub-skills at each session. These skills were as follows:

$>$ Scanning

$>$ Skimming

$>$ Thorough comprehension

$>$ Critical reading

$>$ Summarizing

$>$ Understanding paragraph organization

$>$ Note-taking

$>$ Prediction

\begin{tabular}{|l|l|l|l|l|}
\hline S.No. & Name of the Institution & \multicolumn{2}{|l|}{ Students } & \multirow{2}{*}{ Total } \\
\cline { 3 - 4 } & & Boys & Girls & \\
\hline 1. & $\begin{array}{l}\text { Anna University College of Engineering, } \\
\text { Ramanathapuram, Tamilnadu, India }\end{array}$ & 38 & 38 & 76 \\
\hline
\end{tabular}

\section{Tools}

First of all two valid and reliable tests were utilized for the sake of pretest and posttest. Based on the selected study skills in this study, a pamphlet was prepared. The process of pamphlet preparation lasted three months before the experiment to match with the level of students in this study. Analysis of the data and interpretation

In order to find any differences between two groups a T-test analysis was applied. As the
T-test table illustrates, there is statistically no significant difference between two groups. The result of the analysis of post-test performance after 15 weeks instruction shows that experimental group performed better than the control group. Hence, it can be concluded that there is a direct relationship between study skills and reading comprehension. That is to say, the reading comprehension is highly dependent on the study skills.

Table-2

\begin{tabular}{|l|l|l|l|l|l|}
\hline T-obtained & T-critical & $\mathrm{P}$ & T-obtained & T-critical & $\mathrm{P}$ \\
\hline 1.90 & 1.98 & .50 & 5.22 & 1.98 & .5 \\
\hline
\end{tabular}

VI . Conclusion

The central theme of this research was that, if teachers teach certain study skills of reading and supply the students with necessary tasks and activities to practice those skills, the students comprehension of the target language text will highly improve. Furthermore, the students will grasp the ideas and intentions of the writers very quickly. English foreign language syllabus designers, book developers and test designers need to change their outlook towards teaching and testing reading and provide texts for reading programs in which students are able to apply study skills. 


\section{REFERENCES}

[1] G Bown, J.D. H. Madsen, and A.Hilfery. 2015. TESOL Techniques and Procedures Cambridge: New Bury House Publisher.Inc.

[2] Bright, JA \& McGregor, GP. 2015. Teaching English as a Second Language Longman Group Ltd. London.Clarke, 3.Mark. A. \& Sandra Silberstein. 2014. Reader's Choice University of Michigan Press ELT, London.

[3] Coady, M. 2015. Second Language Reading Development and InstructionDubuque IA: Kendall/Hunt Publishing co.

[4] Pramila Ahu. 2014. Effect of Committed Evaluation Techniques upon Academic Performance Amol Publication Pvt.Ltd., New Delhi.

[5] Rivers, Wilga M. 2015. Teaching Foreign Language Skills. (Seventh Edition) Chicago: The University of Chicago Press.

[6] Samuels. S.J. 2014., What Research Has to say About Reading Instructions Newyork: Inernational Reading Association, Inc.

[7] Water Mary and Alen Waters 2014. "Study skill and Study Competence: Getting the Priorities". ELT Journal Vol.46.

[8] Widdowson, H.G. 2015. A Learning purpose and Language Use. Oxford University Press 